
Time for mapping

MANCHESTER 1824

Manchester University Press 
Sybille Lammes, Chris Perkins, Alex Gekker, Sam Hind, Clancy Wilmott, and Daniel Evans - 9781526122520 Downloaded from manchesterhive.com at $04 / 26 / 2023$ 02:52:38PM 


\section{Time for mapping}

\section{Cartographic temporalities}

EDITED BY SYBILLE LAMMES, CHRIS

PERKINS, ALEX GEKKER, SAM HIND, CLANCY WILMOTT AND DANIEL EVANS 
Copyright (C) Manchester University Press 2018

While copyright in the volume as a whole is vested in Manchester University Press, copyright in individual chapters belongs to their respective authors.

This electronic version has been made freely available under a Creative Commons (CC-BY-NC-ND) licence, thanks to the support of EU Horizon 20/20 project, which permits non-commercial use, distribution and reproduction provided the editor(s), chapter author(s) and Manchester University Press are fully cited and no modifications or adaptations are made. A copy of the licence can be viewed at https:// creativecommons.org/licenses/by-nc-nd/4.0/

Published by Manchester University Press

Altrincham Street, Manchester M1 7JA

www.manchesteruniversitypress.co.uk

British Library Cataloguing-in-Publication Data

A catalogue record for this book is available from the British Library

ISBN 9781526122537 hardback

ISBN 9781526122520 open access

First published 2018

The publisher has no responsibility for the persistence or accuracy of URLs for any external or thirdparty internet websites referred to in this book, and does not guarantee that any content on such websites is, or will remain, accurate or appropriate.

Typeset by

Servis Filmsetting Ltd, Stockport, Cheshire 